\title{
Transient Transformation of Artemisinic Aldehyde $\Delta 11$ (13) Double Bond Reductase (dbr2) Gene into Artemisia annua L.
}

\author{
Elfahmi ${ }^{1,3,}{ }^{,}$, Fany Mutia Cahyani ${ }^{1}$, Andre Ditya Maulana Lubis ${ }^{1}$, Tati Kristanti ${ }^{2}$, \\ Sony Suhandono ${ }^{2}$
}

\author{
${ }^{1}$ School of Pharmacy, Bandung Institute of Technology, Jl. Ganesha 10 Bandung 40132, \\ Indonesia \\ ${ }^{2}$ School of Life Sciences and Technology, Bandung Institute of Technology, \\ Jl. Ganesha 10, Bandung 40132, Indonesia \\ ${ }^{3}$ Biosciences and Biotechnology Research Center, Bandung Institute of Technology, \\ Jl. Ganesha 10 Bandung 40132, Indonesia
}

\begin{abstract}
Global demand of antimalarial drug artemisinin has a gap with production capacity from existing sources since the low content of this compound from Artemia annua L. Genetic engineering-based strategy for A. annua plant on key enzymes in artemisinin biosynthetic pathway is needed. Artemisinic aldehyde $\Delta 11$ (13) double bond reductase (dbr2) is one of the key enzyme on artemisinin biosynthesis which was studied in this research. Agrobacterium tumefaciens-mediated transformation of A. annua using dbr2 was carried out. Synthetic dbr2 was ligated into pCAMBIA1303 and transformed into Escherichia coli DH5a. pCAMBIA1303- $d b r 2$ plasmid was transformed to A. tumefaciens AGL1. Leaves of A. annua were infected by positive transformant of recombinant $A$. tumefaciens $\left(\mathrm{OD}_{600} \approx 1\right)$ supplemented with acetosyringone 50 ppm, and Silwet S-408 0.02\%. Samples were incubated in desiccators connected with vacuum pump, this method is called infiltration vacuum. Leaves were covered in dark for $45 \mathrm{~min}$, and co-cultivated on MS co-cultivation media for 3 days. All leaves were washed in 300 ppm cefotaxime and divided into 2 parts; 3 leaves for GUS histochemical assay and $300 \mathrm{mg}$ of leaves for HPLC analysis. Transient transformation was done in triplicate. In GUS histochemical assay, pCAMBIA1303 and pCAMBIA-dbr2 showed positive blue spot where coefficient of variance was less than 5\%. PCR analysis for genomic DNA of transformed A. annua showed a positive result of inserted $d b r 2$ recombinant indicated by migration profile and direct sequencing analysis. It could be concluded that pCAMBIA-dbr2 construct and transformation into $A$. annua have been successfully performed.
\end{abstract}

Keywords: Artemisia annua L., artemisinin, construction, malaria, pCAMBIA-dbr2, transient

\section{Introduction}

Malaria has already existed since long time ago and become endemic in the tropical and subtropical countries, particularly in South East Asia region including Indonesia. Chloroquine resistant followed by sulfadoxine-pyrimethamine resistant had came up at the end of 1900s causing malaria prevalence increases every year. In early 2000s, Indonesia's Ministry of Health recorded

\footnotetext{
*Corresponding author:

Elfahmi

School of Pharmacy, Bandung Institute of Technology, Jl. Ganesha 10 Bandung 40132, Indonesia

E-mail: elfahmi@fa.itb.ac.id
}

15 million cases of malaria and 38,000 died every year (Depkes RI, 2008), also that 262 million cases and 839,000 people were death globally (WHO, 2015) due to medical failure. In 2001, World Health Organization issued ACTs (Artemisinin based-combined therapies) policy as first-line in malaria treatment caused by drug resistance, firstly tried in Africa region and spread after to others endemic area in the world (WHO, 2015). As the result, mortality number could decrease into $0.92 \%, 0.42 \%$, to 0.2\% from 2005 to 2007 (Depkes RI, 2008).

Indonesia used two ACTs drugs, artesunate-amodiaquine and dihydroartemisinin-piperaquine. These drugs contain artemisinin derived compound which has 
antimalarial activity against Plasmodium sp. parasite at endoeritrocytic stage. Artemisinin was found in Artemisia annua L. plant which has $0.05-0.2 \%$ dried content (Dewick, 2009) thus inhibit commercial production in common. Many efforts have been made such as semisynthetic to enhance artemisinin production as base compound for ACTs. However peroxide bridge structure was unique and hard to be made with common chemical reaction, therefore artemisinin biosynthetic engineering in $A$. annua plant was focused for five key enzymes (Brown, 2010). Artemisinic aldehyde $\Delta 11$ (13)double bond reductase (dbr2) is one of key enzymes which has important role as check point in the path separation to artemisinin. The aim of this study was to transform the $d b r 2$ gene in $A$. annua leaves explant mediated by $A$. tumefaciens.

\section{Materials and Methods}

\section{Materials}

Gene cloning

Escherichia coli DH5a strain; LB med E. coli DH5a strain; LB medium; A. tumefaciens AGL1 strain; YEP medium; CCMB80 buffer; TSS buffer; $\mathrm{CaCl}_{2}$ buffer $20 \mathrm{mM}$; antibiotic selection (kanamycin, rifampicin, and ampicillin); liquid nitrogen; synthetic $d b r 2$ gene plasmid BioBasic Inc. (BBI No. ITB001-2).

\section{Gene construction and confirmation}

Restriction Enzymes: BglII Promega, SpeI Promega, NheI Thermo Scientific, SacI Thermo Scientific; BBuffer ${ }^{\mathrm{TM}}$ Promega; $1 \mathrm{x}$ Tango Buffer ${ }^{\mathrm{TM}}$ Thermo Scientific; T4 DNA
Buffer and Enzyme Ligation Thermo Scientific; Gel/PCR Purification kit Geneaid; Sequencing Primers (Table 1).

\section{PCR analysis}

Dream Taq $^{\mathrm{TM}}$ Green Master Mix; nuclease-free water; 6x Loading Dye DNA Thermo Scientific; Mass ruler DNA ${ }^{\mathrm{TM}}$ ReadyMix Thermo Scientific; Gene ruler1kb ${ }^{\mathrm{TM}}$ Thermo Scientific; Reaction Primers (Table 2). PCR system for $d b r 2$ specific (after optimizing) using 25 cycle, with $95^{\circ} \mathrm{C}$ for 3 min pre and $30 \mathrm{~s}, 46^{\circ} \mathrm{C}$ for $30 \mathrm{~s}$, and $72^{\circ} \mathrm{C}$ for $1.5 \mathrm{~min}$ and $7 \mathrm{~min}$ extension, then CaMV35S - GUS PCR system using 25 cycle, with $95^{\circ} \mathrm{C}$ for $3 \mathrm{~min}$ pre and $30 \mathrm{~s}, 60^{\circ} \mathrm{C}$ for $30 \mathrm{~s}$, and $72^{\circ} \mathrm{C}$ for $1.5 \mathrm{~min}$ and $7 \mathrm{~min}$ extension.

\section{Plant transformation}

A. annua from Tawangmangu, Central Java, Indonesia; ethanol 70\%; sodium hypochlorite $0.75 \%$; acetosyringone; Silwet S-408; cefotaxime; mediums (Table 3 ).

\section{GUS histochemical assay}

For $100 \mathrm{~mL}$ solution contain: X-Gluc $52.5 \mathrm{mg}$, phosphate buffer $1 \mathrm{M}(\mathrm{pH} 7) 5 \mathrm{~mL}$, Triton-X $0.1 \mathrm{~mL}$, and add to 100 with Aqua Deion Steril.

\section{Gene isolation}

Reagent for plasmid isolation containing: Solution 1 [glucose $50 \mathrm{mM}$, Tris $\mathrm{Cl} 25 \mathrm{mM}$, EDTA (pH 8) 10mM], Solution 2 [ $\mathrm{NaOH} 0.2$ $\mathrm{N}$, SDS $2 \% \mathrm{w} / \mathrm{v}$ ], Solution 3 [NaOAc5 M, Glacial acetic acid], isopropanol, ethanol 70\%, and TE-RNAse; Plant Genomic Isolation kit Geneshun.

Table 1. Primer sequences for sequencing analysis.

\begin{tabular}{ll}
\hline Primer Name & Sequence \\
\hline Primer_DBR_Forward & 5'-GCCTACAAGATGGGCAAG-3' \\
Primer_3_DBR_Reverse & 5'-TTGTGAGCTGCATCAACCAC-3' \\
Primer_CaMV_35S_Forward & 5'-ATAGAGGACCTAACAGAACTCG-3' \\
Primer_3_GUS_Reverse & 5'-TTCCACAGTTTTCGCGATCC-3' \\
\hline
\end{tabular}

Table 2. Primer specific sequences.

\begin{tabular}{ll}
\hline Primer Name & Sequence \\
\hline dbr2F & 5'-GCCTACAAGATGGGCAAG-3' \\
dbr2R & 5'-CTAGAGGAGTGACCCTTTG-3' \\
FCaMV_35S & 5'-ATAGAGGACCTAACAGAACTCG-3' \\
RGUS & 5'-TTCCACAGTTTTCGCGATCC-3' \\
\hline
\end{tabular}


Table 3. Plant medium composition.

\begin{tabular}{ll}
\hline Medium & Composition \\
\hline Co-cultivation & MS Salt full, Sucrose 3\%, Agar 0,8\% $(\mathrm{pH}=5.8)$ \\
Infection & $1 / 2$ MS Salt, Sucrose 3\% $(\mathrm{pH}=5.8)$ \\
\hline
\end{tabular}

\section{Methods}

\section{Plasmid construction}

A good sample of pCAMBIA133 and pUC57- $d b r 2$ vector was chosen by migration profile from the result of polymerase chain reaction confirmation. Those vector were set as templates for restriction reaction with $B g l \mathrm{I}$ and SpeI enzymes. The restriction reactions were separated by $1 \%$ agarose gel electrophoresis and cut at the desired band size, then purified it with Gel/PCR Purification kit Geneaid. All elution liquids collected from same sample were pooled in one tube, then defined the final concentration using Multidrop Thermo Scientific Multiskan $\mathrm{Go}^{\mathrm{TM}}$ followed by checking the existence of desired fragment size with gel electrophoresis. Gen and vector were ligated with T4 DNA ligation enzyme, incubated at $22^{\circ} \mathrm{C}$ for an hour then all of reaction were introduced into E. coli DH5a competent cell and transferred to LB medium with antibiotic selection, incubate at $37^{\circ} \mathrm{C}$ overnight (Table 4).

\section{Confirmation of plasmid}

All positive transformants were grown overnight in LB medium with antibiotic selection. Recombinant plasmids were isolated using solution 1 (GTE solution), 2 ( $\mathrm{NaOH}$ SDS solution), and 3 (KOAc solution), then ends up DNA pellet reconstituted with TERNAse. Plasmid solution was diluted to 20x factor. Furthermore plasmids were confirmed by migration analysis with following procedures put $5 \mu \mathrm{L}$ of plasmid into $0.8 \%$ agarose gel and run electrophoresis 30 minute, $100 \mathrm{~V}$; PCR analysis in following procedures: set PCR reaction with $d b r 2$ specific primers and run the system as describe above. Screen the result in 1\% agarose gel electrophoresis; restriction analysis with following procedures: set restriction reaction with $\mathrm{NheI}$ and $\mathrm{SacI}$ enzyme incubate 3 hours at $37^{\circ} \mathrm{C}$. Separate by $0.8 \%$ agarose gel electrophoresis, and analyze the fragment size pattern; and DNA Sequence Analysis with following procedures $20 \mu \mathrm{L}$ plasmid (undiluted) was send to Macrogen Inc., South Korea, to take sequence analysis with existing primer for sequencing.

Cloning the plasmids in Agrobacterium tumefaciens Chemically competent cell of $A$. tumefaciens AGL1 were prepared using liquid nitrogen method (Chen et al., 1994), then pCAMBIA- $d b r 2$ plasmid were transformed into the competent cell with YEP medium (+ rRifampicin 50 ppm, ampicillinA 100 ppm, and kKanamycin $50 \mathrm{ppm}$ ). The recombinant cells were incubated for three days covered in dark at room temperature. Positive colonies were analyzsed with crude PCR with CaMV35s - GUS PCR system.

Transient transformation of $p$ CAMBIA1302-dbr2 into Artemisia annua $L$.

Hundreds mg leaves explant near shoot apical were weighed and sterilized with ethanol $70 \%$ for $1 \mathrm{~min}$, sodium hypochlorite $0 ., 75 \%$ for $15 \mathrm{~min}$, then rinsed 3 times with sterilized aquadest for $5 \mathrm{~min}$. Overnight culture $\left(\mathrm{OD}_{600} \approx 1\right)$ of positive $A$. tumefaciens transformants was pelleted, then mixed with sterile explant in MS medium, acetosyringone 50 ppm, and Silwet S-408 0.02\%. The mixture was vacuum for $45 \mathrm{~min}$ in dark room temperature, and it was placed in MS-cocultivation in 3 days covered in dark. After that it was washed in cefotaxime 200 ppm, rinsed 3 times and dried.

Analysis of gene in transformed Artemisia annua L.

A few leaves were vacuumed in GUS staining solution then store in room temperature 3 days and measure blue spot area with ImageJ software. Another leaves were prepared for genomic isolation with Plant Genomic Isolation kit Geneshun. Genomic samples were set in PCR reaction with FCaMV35S and RGUS primer and run system as described above. 
Table 4. pCAMBIA-dbr2 ligation reaction composition.

\begin{tabular}{lllll}
\hline & $\begin{array}{l}\text { Initial } \\
\text { Concentration }\end{array}$ & $\begin{array}{l}\text { Final } \\
\text { Concentration }\end{array}$ & Sample & $\begin{array}{l}\text { Ligation } \\
\text { Control }\end{array}$ \\
\hline $\begin{array}{l}\text { Nuclease-free water } \\
\text { dbr2 fragment }\end{array}$ & - & - & $8.8 \mu \mathrm{L}$ & $16.8 \mu \mathrm{L}$ \\
pCAMBIA1303 & $23 \mathrm{ng} / \mu \mathrm{L}$ & $\pm 160 \mathrm{ng}$ & $8 \mu \mathrm{L}$ & - \\
fragment & $94 \mathrm{ng} / \mu \mathrm{L}$ & $\pm 100 \mathrm{ng}$ & $1 \mu \mathrm{L}$ & $1 \mu \mathrm{L}$ \\
T4 DNA Ligase Buffer & $10 \mathrm{x}$ & $1 \mathrm{x}$ & $2 \mu \mathrm{L}$ & $2 \mu \mathrm{L}$ \\
T4 DNA Ligase Enzyme & 5 Weiss Unit $/ \mu \mathrm{L}$ & 1 Weiss Unit & $\underline{0.2 \mu \mathrm{L}+}$ & $\underline{0.2 \mu \mathrm{L}+}$ \\
& & & $20 \mu \mathrm{L}$ & $20 \mu \mathrm{L}$ \\
\hline
\end{tabular}

\section{Results and Discussion}

Plasmid samples in stock were checked by gel electrophoresis to ensure quality and intensity of plasmid band. The presence of DNA ladder was being as a reference of samples migration with each other. A bold and clear band with high intensity like plasmid from C, D, E, and F (Figure 1) indicated a good plasmid. In order to improve efficiency and effectiveness of restriction reaction, a double digest method were done using Buffer $\mathrm{B}^{\mathrm{TM}}$ Promega with 2-fold BglII concentration consequently. This could reduce purification step which tend to increase the concentration at last. $\mathrm{pC} 1$ and $\mathrm{pC} 2$ fragments could be preconcerted with a complete restriction because of two enzymes have managed to cut pUC57-dbr2 plasmid in 2 fragments as desired, since the distance between two restriction sites just $7 \mathrm{bp}$ (out of gel). To obtain high final concentration after purification, total elution buffer was reduced then two or more same fragment gels were purified and collected altogether into one tube, which $\mathrm{pC} 1$

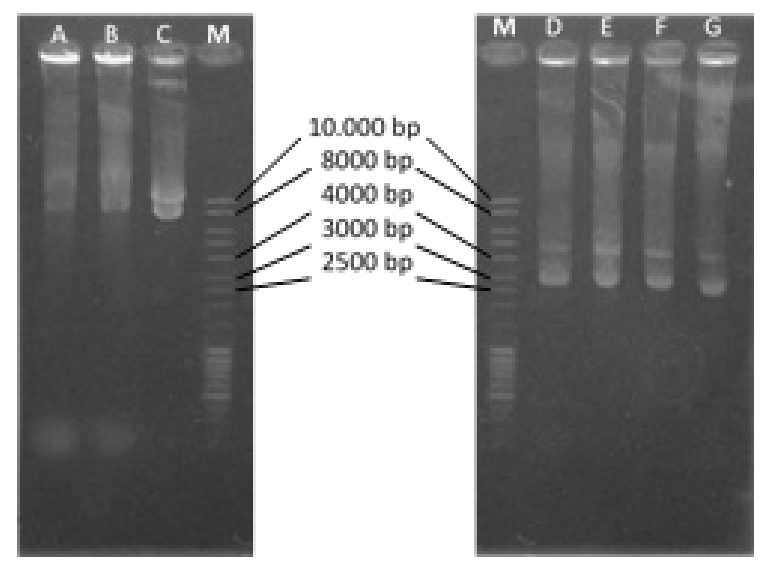

Figure 1. Electrophoregram of $A-C=$ pCAMBIA1303, $\mathrm{D}-\mathrm{G}=\mathrm{pUC} 57-d b r 2$ migration relative to $\mathrm{M}=\mathrm{DNA}$ ladder. with pC2 and D1, D2, D3, with D4 (Figure 2). All purified samples then were checked by its existency (boldness and clearness of fragment band) and quality (concentration and purity) to ensure a fragment condition after purification (Table 5). The purification results were a good with bold and clear band also quite high of concentration and purity (Figure 3), thus the ligation reaction with high success rate would be achieved. Composition of ligation 1:8 (pCAMBIA1303:dbr2) was used regard to the amount of insert $(d b r 2)$ should be more than vector (pCAMBIA1303). Based on the comparison of concentration value, $d b r 2$ fragment has to be 8 times more than pCAMBIA1303 to make an effective collision in reaction. After one hour incubation at $22^{\circ} \mathrm{C}$ temperature, all samples were transformed into E. coli $\mathrm{DH} 5$ a with suitable antibiotic selection.

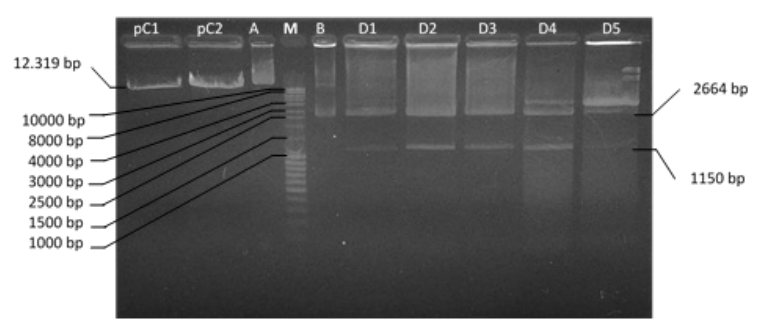

Figure 2. Electrophoregram of restriction fragment size of $\mathrm{pC} 1$ and $\mathrm{pC} 2=$ pCAMBIA1303, D1-D5 = pUC57 dbr2 with BglII and SpeI compared to uncut A = pCAMBIA1303, $\mathrm{B}=$ pUC57- $d b r 2$ plasmid, DNA ladder $(\mathrm{M})$.

Table 5. Absorbance measurement of purified fragment at $260 \mathrm{~nm}$ and $280 \mathrm{~nm}$..

\begin{tabular}{lccr}
\hline Maximum & \multicolumn{3}{c}{ Absorbance } \\
\cline { 2 - 4 } Wavelength & Blank & pCAMBIA1303 & \multicolumn{1}{c}{ dbr2 } \\
\hline $260 \mathrm{~nm}$ & 0.058 & 0.156 & 0.082 \\
$280 \mathrm{~nm}$ & 0.051 & 0.101 & 0.063 \\
Concentration $(\mathrm{ng} / \mu \mathrm{L})$ & & 94.230 & 23.080 \\
Purity $\left(\mathrm{A}_{260} / \mathrm{A}_{280}\right)$ & & 1.960 & 2.000 \\
\hline
\end{tabular}




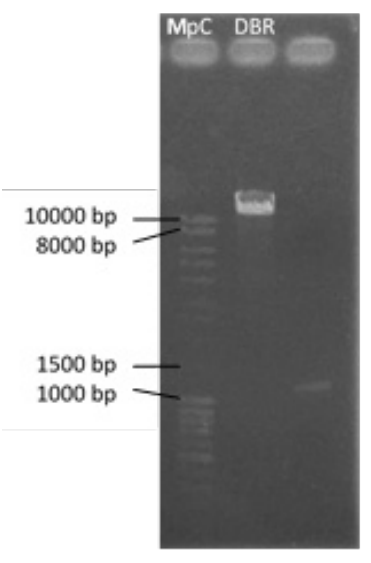

Figure 3. Electrophoregram result to check the presence and size conformity of $\mathrm{pC}=\mathrm{pCAMBIA1303}$ and DBR $=d b r 2$ fragment.

Figure 4 showed that all transformation process were successful due to clean negative transformation control where not contaminated with other microorganism were not found and the cell competency were still good enough due to positive transformation result. Ligation control was made to confirm so the colony grows in ligation sample transformant were not false positive. All of the colony in plate A were picked into LB medium to isolate their plasmid. After isolation, dissolved plasmid was diluted with 20 times factor to set as template for confirmation procedure.

First confirmation would be a comparison of migration profile has a desired result that isolated plasmid were slower (have short migration) than pCAMBIA1303 (Figure 5). This should indicate that a isolated plasmid have weighs heavier because of inserted $\mathrm{dbr} 2$ gene, but this result could not be as strong evidence. Next confirmation was restriction analysis between inserted vector with empty vector. As the result, a different pattern of

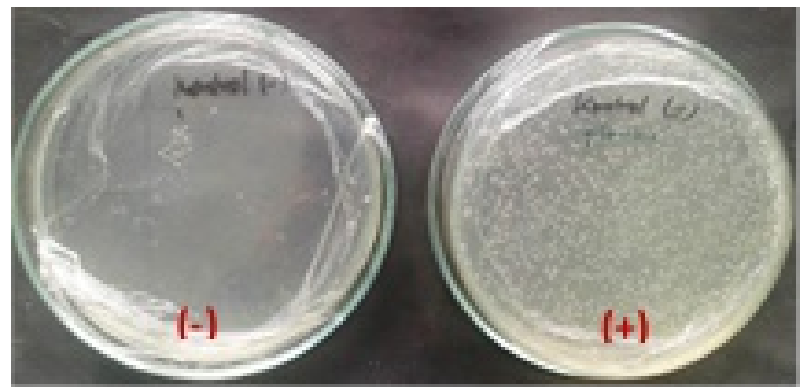

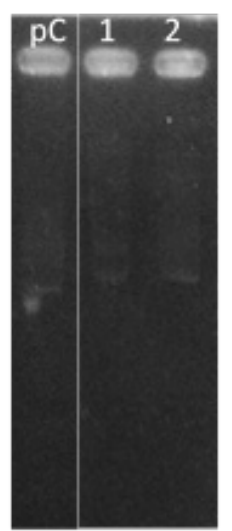

Figure 5. Electrophoregram of migration profile comparison between isolated plasmid 1 and $2=$ colony 1 and 2, with $\mathrm{pC}=$ pCAMBIA1303.

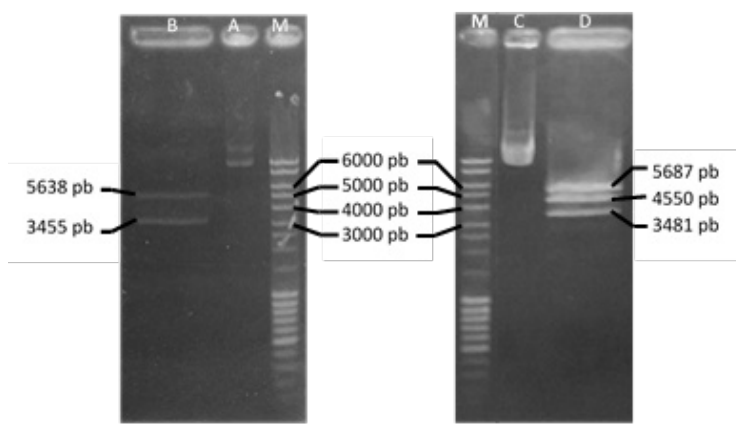

Figure 6. Electrophoregram of restriction analysis between $\mathrm{D}=$ isolated plasmid and $\mathrm{B}=$ pCAMBIA1303 relative to uncut plasmid $C$ and $A$ respectively.

fragment that indicates different size between them (Figure 6). In fact, the reason for using NheI and SacI enzyme provided the same number of fragments (theoretically three) but has different size. Although first and third fragment size were the same (around 5600 bp and $3400 \mathrm{bp}$ ), the second fragment size showed differences, for empty vector the fragment size was similar to the third fragment (around $3300 \mathrm{bp}$ ) so that it looks like one fragment instead of two (Figure 6). It could be imagined from inserted vector simulation

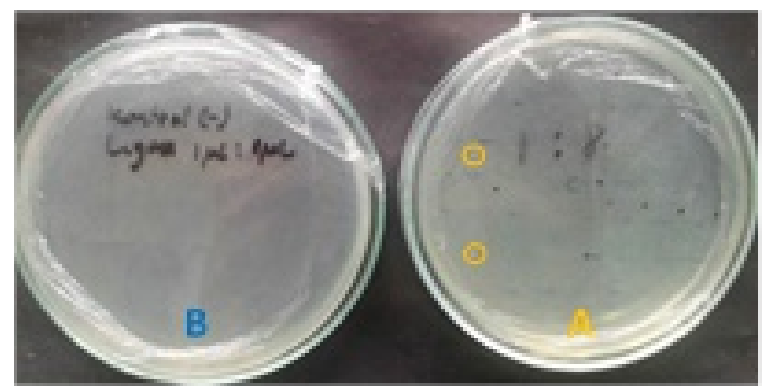

Figure 4. Transformation result of $(-)=$ negative transformation control, $(+)$ positive transformation control, $\mathrm{B}=$ ligation control, and $\mathrm{A}=$ ligation sample. 


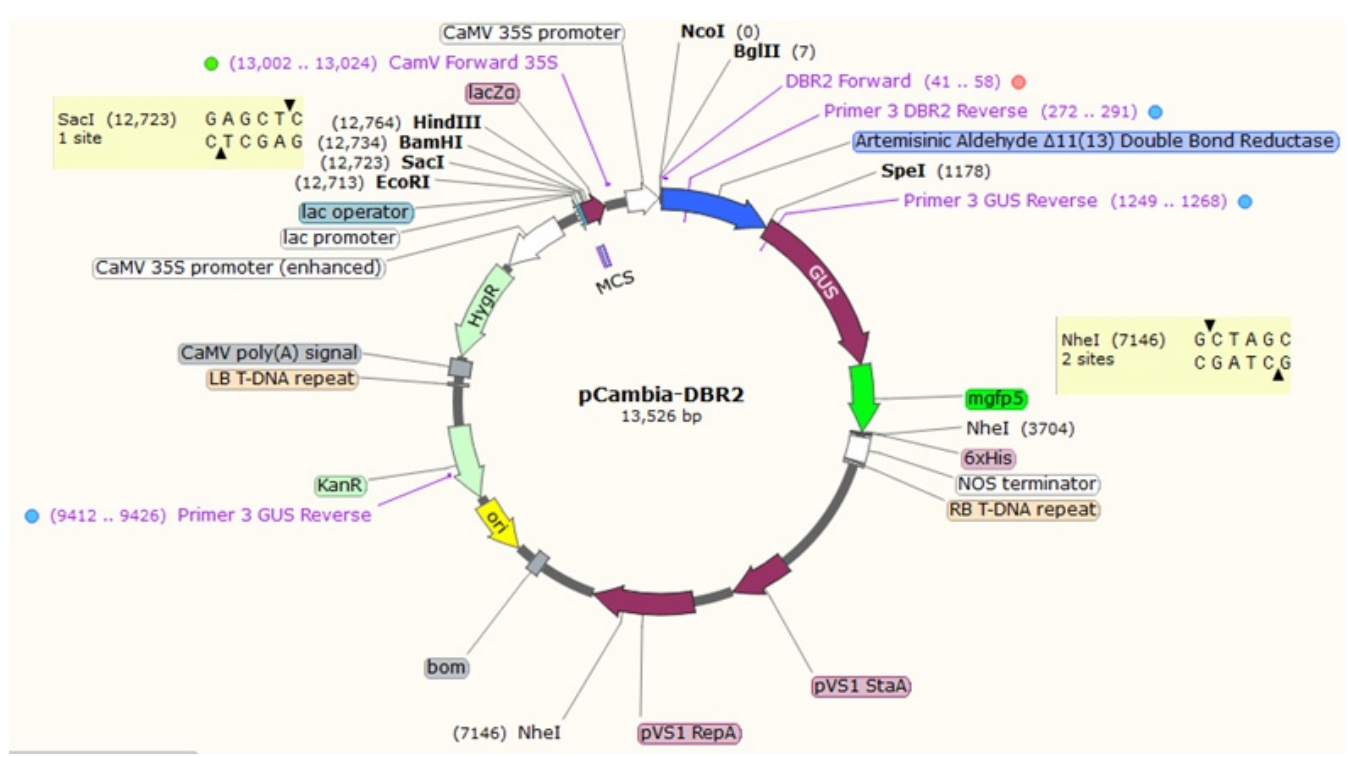

Figure 7. pCAMBIA-dbr2 map simulation with NheI and SacI restriction sites at NOS terminator, $p V S 1$ RepA, and MCS are respectively.

(Figure 7) that $d b r 2$ insert gene make the fragment becomes longer. This analysis also could not strengthening the existing evidence because the addition of fragment size could be from any genetic material not specifically mention it was $d b r 2$ gene. Therefore, further confirmation analysis was needed.

Further confirmation was PCR analysis using $d b r 2$ specific primer with pUC57-dbr2 as a positive control. Optimization of annealing temperature was needed to be done using gradient PCR to get the suitable PCR system. The right annealing temperature has bold and clear amplification band than others, therefore lane $\mathrm{H}$ was the right one (Figure 8), then $d b r 2$ specific system was set $46^{\circ} \mathrm{C}$ for annealing temperature. Isolated plasmid were confirmed using optimized PCR system. As the result, two band samples were linear with positive control at around 1110 bp (Figure 9),

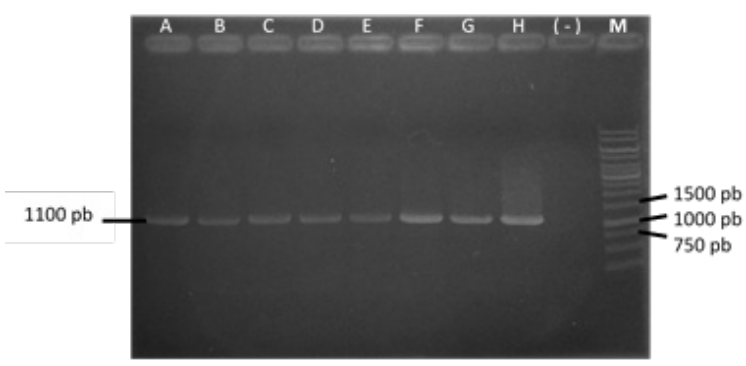

Figure 8. Electrophoregram of optimizing annealing temperature at $\mathrm{A}=53,0^{\circ} \mathrm{C}, \mathrm{B}=52,4^{\circ} \mathrm{C}, \mathrm{C}=51,6^{\circ} \mathrm{C}, \mathrm{D}=$ $50,4^{\circ} \mathrm{C}, \mathrm{E}=48,7^{\circ} \mathrm{C}, \mathrm{F}=47,3^{\circ} \mathrm{C}, \mathrm{G}=46,5^{\circ} \mathrm{C}, \mathrm{H}=46,0^{\circ} \mathrm{C}$, with $(-)$ = negative control. it could be ascertained the plasmid samples have $d b r 2$ inserted gene. For the purpose of artemisinin biosynthetic engineering, how the nucleotide sequence and reading position was important, and the previous result was not strong enough to convince that plasmid system would be expressed well. To overcome these doubts, DNA sequencing analysis was performed using Macrogen's service as a third party. Firstly, the samples was analyzed using two primers (CaMV35S Forward and primer 3 DBR Reverse) and the result was identical with Genebank database, then to complete ORF sequences, two other primers (DBR Forward and primer 3 GUS Reverse) were used. These four sequences result was combined using BioEdit program, then use nucleotide BLAST ${ }^{\mathrm{TM}}$ tools from NCBI to be compared with database. Identity value reached $100 \%$ score for $d b r 2$, it means the

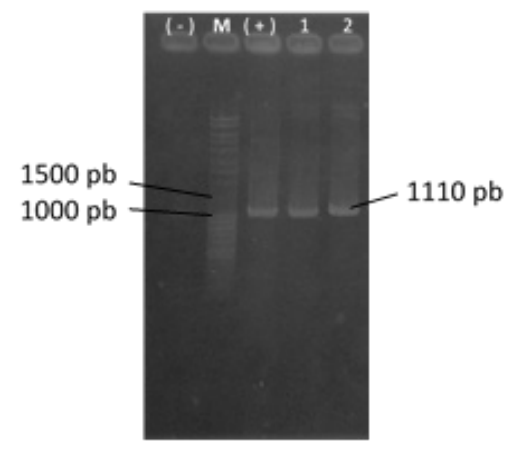

Figure 9. Electrophoregram of PCR analysis from 1 and 2 = isolated plasmid compared with DNA ladder (M). 


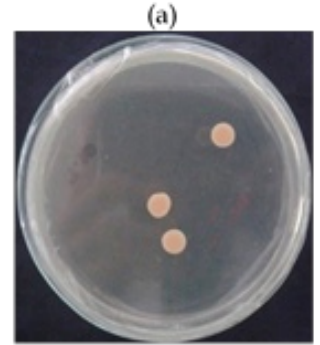

(c)

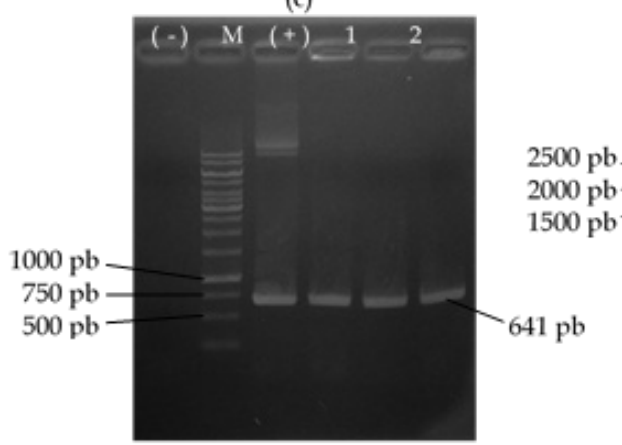

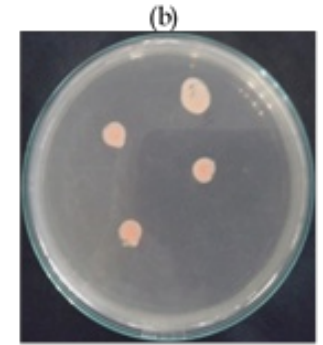

(d)

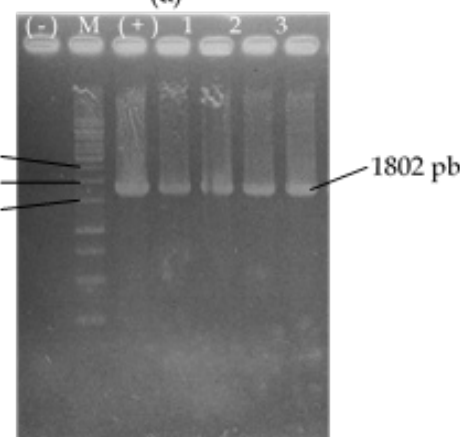

Figure 10. A. tumefaciens AGL1 transformant contains A = pCAMBIA1303, and B = pCAMBIA-dbr2 as evidenced by electrophoregram of crude PCR C and D respectively.

whole sequence of $d b r 2$ was completely similar to sequence from library. Because of similarity with database, it should strongly concluded that gene construct was successfully done.

Confirmed pCAMBIA- $d b r 2$ and pCAMBIA1303 plasmid were transformed into A. tumefaciens AGL1 competent cell to get recombinant transformed colonies. To ensure that colonies contain desired gene, crude colony PCR was done with all of grown colonies on the plate medium (Figure 10). All of PCR product indicates all colonies were positive due to comparison with control plasmid. Next step was genetic transformation into $A$. annua which was mediated by A. tumefaciens AGL1 recombinant. This stage was performed using four groups of transformation: pCAMBIA-dbr2, pCAMBIA1303, AGL1 (wild type), and without transformation (plant wild type). The aim of this treatment was to observe the gene expression in short period of time, so called transient transformation. Transient transformation was a preliminary test to determine level of transformation and expression result of transferred gene. The transformation was preceded by harvesting A. tumefaciens

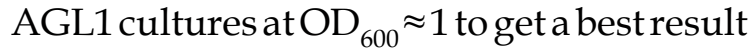
of transfection (Chamidah, 2013). Strain AGL1 has hypervirulent properties than others and made a tough transformation result using GUS histochemical evaluation (Elfahmi, 2014) so it was chosen. This study used a young leaves (near apical) explant to proceed $d b r 2$ gene transformation, because it has either minimum contaminant or minimum barrier that possible for $A$. tumefaciens infection and also in this part has amount of artemisinin than others.

Acetosyringone as a phenolic compound would trigger gene delivery system through signal transduction mechanism in $A$. tumefaciens cell surface. Silwet S-408 is organosilicon surfactant acts to lower surface tension between bacteria and plant cell, this

Table 6. Measurement area of blue spot of leaves using ImageJ software.

\begin{tabular}{lccccc}
\hline \multirow{2}{*}{ Treatment Group } & \multicolumn{3}{c}{ Repetition } & $\begin{array}{c}\text { Mean Proportion } \\
\text { of Blue Spot }(\%)\end{array}$ & $\begin{array}{c}\text { Coefficient of } \\
\text { Variance }(\%)\end{array}$ \\
\cline { 2 - 4 } & 1 & 2 & 3 & $95.63 \%$ & $1.29 \%$ \\
pCAMBIA1303 & $94.63 \%$ & $97.37 \%$ & $94.89 \%$ & $92.73 \%$ & $1.21 \%$ \\
pCAMBIA-dbr2 & $94.31 \%$ & $91.90 \%$ & $91.97 \%$ & 0 & 0 \\
AGL1 & 0 & 0 & & 0 & 0 \\
TT & 0 & 0 & & & 0 \\
\hline
\end{tabular}


type of surfactant gave the best transformation result compared with other series (Chahyadi, 2011), concomitant use with acetosyringone could increase transformation efficiency. Agrobacterium-mediated gene transformation efficiency could be enhanced using vacuum infiltration method by creating negative atmospheric pressure conditions then the air in the space between plant cells reduced and facilitate the bacteria to have direct contact with the cells. After three days cocultivation, leaves explant were washed by cefotaxime to kill excessive bacteria attached to the leaves, and were divided for subsequent expression confirmation.

The blue spot on pCAMBIA- $d b r 2$ leaves transformant after GUS histochemical assay showed an expression of GUS reporter gene that linked to the $d b r 2$ gene, it means that two genes has been in-frame (Figure 11). Percentage of blue spot area in triplicate indicates level of gene expression area, the wider of blue spot area the better transformation efficiency Table 6). Staining time to get blue spot area for its triplicate were in 3 days, 5 days, and 4 days respectively. The difference of staining time was caused by the sensitivity of stored $X$ Gluc staining solution diminished over time. However, repeatability of transformation method could still be accepted due to $\mathrm{CV}$ (coefficient of variance) value was below $5 \%$ relatively.

To determine the existence of $d b r 2$ gene recombinant on pCAMBIA-dbr2 leaves transformant, DNA genomic isolation was performed. It was used as a template for PCR reaction with primer of FCaMV35S and RGUS
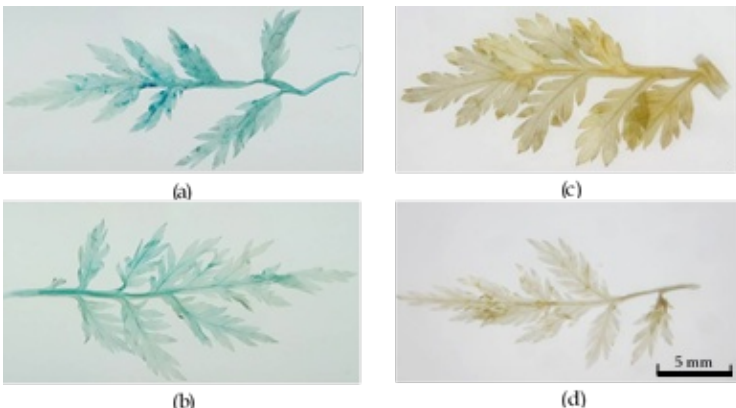

Figure 11. Leaves of GUS staining result for $A=$ pCAMBIA1303, $\mathrm{B}=$ pCAMBIA- $d b r 2, \mathrm{C}=\mathrm{AGL1}, \mathrm{D}=$ without transformation.

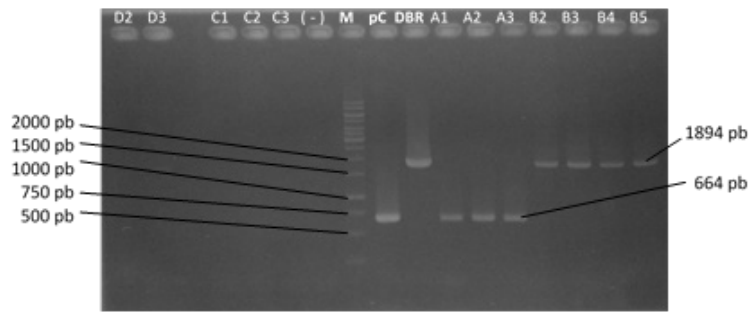

Figure 12. Electrophoregram of PCR product of isolated leaves genomic from transformant of $\mathrm{A} 1-\mathrm{A} 3=$ pcAMBIA1303, B2-B5 = pCAMBIA-dbr2, C1-C3 = AGL1, D2 and D3 = without transformation are compared with result of $\mathrm{pC}=$ pCAMBIA1303 plasmid, $\mathrm{DBR}=$ pCAMBIA- $d b r 2$ plasmid control

in spite of $d b r 2$ specific primer because it would give bias result with the existing $d b r 2$ native gene in wild type genomic DNA. There was PCR product band with $664 \mathrm{bp}$ size at A1-A3 lane same as pCAMBIA1303 band control which size of CaMV35S to GUS primer region, yet product band at B2-B5 lane have 1894 bp size (Figure 12) means have extra around $1230 \mathrm{bp}$ which is similar to inserted $d b r 2$ gene size.

\section{Conclusions}

Gene construction of artemisinic aldehyde $\Delta 11$ (13) double bond reductase (dbr2) into pCAMBIA1303 binary vector has been successfully preconcerted after through four steps confirmation test. GUS histochemical assay after pCAMBIA-dbr2 transient transformation provide the blue spot area which means $d b r 2$ gene has been transformed as was in-frame to GUS reporter gene and its existence was proved by PCR of genomic DNA. Verification of dihydroartemisinic aldehyde and artemisinin content is needed between non-recombinant compared to recombinant transformant.

\section{References}

Brown, G.D. 2010. The biosynthesis of artemisinin (Qinghaosu) and the phytochemistry of Artemisia annua L. Molecules, 15, 7603-7698,

Cahyadi, A. (2011) Transformasi genetik Artemisia annua L. menggunakan Agrobacterium dalam rangka produksi artemisinin. Master's thesis, School of Pharmacy ITB, Bandung.

Cahyani, F.M. (2016) Transformasi gen 
Amorpha-4,11-Dien Synthase (ADS) dan Protein 19 (P19) pada tumbuhan Artemisia annua L. serta pengaruhnya terhadap kandungan artemisinin sebagai antimalaria. Master's thesis, School of Pharmacy ITB, Bandung.

Chamidah, N. (2013) Transformasi gen Amorfa4,11-Dien Sintase (ADS) ke dalam kultur in vitro Artemisia annua L. menggunakan Agrobacterium tumefaciens AGL-1 untuk meningkatkan kadar artemisinin. Bachelor thesis, School of Pharmacy ITB, Bandung.

Chen, H., Nelson, R.S., and Sherwood, J.L. 1994. Enhanced recovery of transformants of Agrobacterium tumefaciens after freeze-thaw transformation and drug selection. BioTechniques, 16(4), 664-670.

Covello, P.S., Teoh, K.H., Polichuk, D.R., Reed, D.W., and Nowak, G. 2007. Functional genomics and the biosynthesis of artemisinin. Phytochemistry, 68, 1864-1871.

Depkes RI. (2008) Infodatin: situasi malaria di Indonesia, Depkes RI, Jakarta.

Dewick, P.M. (2009) Medicinal natural products: a biosynthetic approach. West Sussex: John Wiley \& Sons Ltd. pp. 197-199.

Elfahmi, Suhandono, S., Cahyadi, A. 2014. Optimization of genetic transformation of Artemisia annua L. using Agrobacterium for artemisinin production. Pharmacogn. Mag. 10 (Suppl 1), S176-S180.

Jefferson, R.A. 1987. Assaying chimeric genes in plants: the GUS gene fusion system, Plant Mol. Biol. Rep., 5(4), 387-405.

Komari, T., Takakura, Y., Ueki, J., Kato, N., Ishida, Y., and Hiei, Y. (2006) Binary vectors and Super-binary vectors, In: Wang K (ed), Agrobacterium protocols 2nd ed., vol. 1. New Jersey: Humana Press. pp. 15-42.

Koo, J., Kim, Y., Kim, J., Yeom, M., Lee, I.C., and Nam, H.G. 2007. A GUS/luciferase fusion reporter for plant gene trapping and for assay of promoter activity with luciferin-dependent control of the reporter protein stability. Plant Cell Physiol., 48(8), 1121-1131.

Lee, L.Y., and Gelvin, S.B. 2008. T-DNA binary vectors and systems. Plant Physiol., 146, 325-332.

Leuzinger, K., Dent, M., Hurtado, J., Stahnke, J., Lai, H., Zhou, X., and Chen, Q. 2013. Efficient agroinfiltration of plants for high-level transient expression of recombinant proteins. J. Visualized Exp., 77, 1-9.

Martin, T., Wöhner, R.V., Hummel, S., Willmitzer, L., and Frommer, W.B. (1992) The GUS reporter system as a tool to study plant gene expression, In: Gallagher SR (ed), GUS protocols: using the GUS gene as a reporter of gene expression. San Diego: Academic Press Inc. pp. 23-39.

Michelis, C.B., Hooykaas, P.J.J., Hondel, C.A.M.J.J., and Ram, A.F.J. 2008. Agrobacterium-mediated transformation of the filamentous fungus Aspergillus awamori, Nat. Protoc., 3(10), 1671-1678.

Nguyen, K.T., and Arsenault, P.R. 2011. Trichomes + roots $+\mathrm{ROS}=$ Artemisinin: regulating artemisinin biosynthesis in Artemisia annua L. in vitro cell. Dev. Biol. - Plant, 47, 329-338.

Olofsson, L., Engström, A., Lundgren, A., and Brodelius, P.E. 2011. Relative expression of genes of terpene metabolism in different tissues of Artemisia annua L.. BMC Plant Biol., 11, 45.

Rao, A.Q., Bakhsh, A., Kiani, S., Shahzad, K., Shahid, A.A., Husnain, T., and Riazuddin, S. 2009. The myth of plant transformation, Biotechnol. Adv., 27, 753-763.

Rivera, A.L., Lim, M.G., Fernández, F., and Loske, A.M. 2012. Physical methods for genetic plant transformation. Phys. Life Rev., 9, 308-345.

Ruijter, N.C.Ad., Verhees, J., Leuween, Wv., and Krol, Arvd. 2003. Evaluation and comparison of the GUS, LUC and GFP reporter system for gene expression studies in plants. Plant Biol., 5, 105-113. 
Sambrook, J., Russell, D.W. (2001) Molecular Cloning: A laboratory manual, 3rd ed., New York: Cold Spring Harbor Laboratory Press.

Simmons, C.W., Gheynst, J.Svd., and Upadhyaya, S.K. 2009. A model of Agrobacterium tumefaciens vacuum infiltration into harvested leaf tissue and subsequent in planta transgene transient expression. Biotechnol. Bioeng. 102(3), 965-970.

Tang, K., Shen, Q., Yan, T., and Fu, X. 2014. Transgenic approach to increase artemisinin content in Artemisia anпиа L. Plant Cell Rep., 33(4), 605-615.

WHO (2015) World malaria report 2015. Geneva: World Health Organization.

Yuan, Y., Liu, W., Zhang, Q., Xiang, L., Liu, X., Chen, M., Lin, Z., Wang, Q., and Liao, Z. 2015. Overexpression of artemisinic aldehyde $\Delta 11$ (13) reductase gene-enhanced artemisinin and its relative metabolite biosynthesis in transgenic Artemisia annua L. Biotechnol. Appl. Biochem., 62(1), 17-23.

Zhang, Y.S., Teoh, K.H., Reed, D.W., Maes, L., Goossens, A., Olson, D.J., Ross, A.R., and Covello, P.S. 2008. The molecular cloning of artemisinic aldehyde delta11(13) reductase and its role in glandular trichome-dependent biosynthesis of artemisinin in Artemisia annua. J. Biol. Chem., 283(31), 21501-21508. 